\title{
人工市場アプローチによる介入エージェントを 用いた為替介入効果の分析
}

\section{Analysis of Foreign Exchange Interventions by Intervention Agent with an Artificial Market Approach}

\author{
松井 宏樹＼cjkstart北陸先端科学技術大学院大学情報科学研究科 \\ School of Information Science, Japan Advanced Institute of Science and Technology \\ hmatui@jaist.ac.jp \\ $\begin{array}{ll}\text { 東条 敏 } & \text { (同 } \underset{\text { Satoshi Tojo }}{\text { tojo@jaist.ac.jp }}\end{array}$
}

keywords: artificial market, multi-agent system, foreign exchange market, reinforcement learning, complex system

\section{Summary}

We propose a multi-agent system which learns intervention policies and evaluates the effect of interventions in an artificial foreign exchange market. Izumi et al. had presented a system called AGEDASI TOF to simulate artificial market, together with a support system for the government to decide foreign exchange policies. However, the system needed to fix the amount of governmental intervention prior to the simulation, and was not realistic. In addition, the interventions in the system did not affect supply and demand of currencies; thus we could not discuss the effect of intervention correctly. First, we improve the system so as to make much of the weights of influential factors. Thereafter, we introduce an intervention agent that has the role of the central bank to stabilize the market. We could show that the agent learned the effective intervention policies through the reinforcement learning, and that the exchange rate converged to a certain extent in the expected range. We could also estimate the amount of intervention, showing the efficacy of signaling. In this model, in order to investigate the aliasing of the perception of the intervention agent, we introduced a pseudo-agent who was supposed to be able to observe all the behaviors of dealer agents; with this super-agent, we discussed the adequate granularity for a market state description.

\section{1.はじめに}

2003 年，日本政府は外国為替市場において 1 年間で 20 兆円以上もの米ドル買い介入を行っている [財務 04] . 全体的に見ればこの操作が円高を防いだことは明らかで ある．しかし，これだけ巨額な介入を行っているにもか かわらず, 常に為替レートが円安の状態で安定していた わけではない . ときに大きな円高への変動すら経験して いる．では，介入は市場にどのように影響するのであろ うか. また，有効な介入とはどのようなものであろうか .

本研究で用いる人工市場とは, マルチェージェントモ デルとして計算機上に作り出された架空の市場のことで ある . 市場参加者である複数のエージェントを計算機上 の市場で取引させることで市場に起こる樣々な現象のシ ミュレーションを行う.計算機プログラムであるので, 現 実には起こりえない状況でのシミュレーションを行ったり 現実では知ることの難しい各市場参加者の投機行動など のデータを得ることが可能である .この特徵を活かして， 従来の経済理論では説明できなかった市場現象の解析な どが行われている．また，人工市場をマルチェージェン
トモデルとして分類すると多数のエージェントが共通の 目的を達成するために行動するモデルではなく，各エー ジェントが炎れぞれの目的のために行動する競合モデル ということができる . 本研究の目的は, 外国為替市場に おける介入の影響と炎のメカニズムを人工市場アプロー チにより分析することである．

本論文では, 2 章で本研究で用いる人工市場モデルに ついて，3章で現実の中央銀行に相当する介入ェージェ ントについて説明する . 4 章でこのモデルを用いた介入 の効果の検証実験について，5章では 4 章で報告した実 験の検証について光れ光れ報告する．最後に 6 章で考察 と今後の課題についてまとめる .

\section{2. 人工市場モデル}

本研究では和泉らの作成した AGEDASI TOF*1 [和 泉 00] を基にした人工市場モデルを用いている．本章で は AGEDASI TOF と钅の改良点について述べる .

\footnotetext{
*1 A GEnetic-algorithmic Double Auction SImulation in TOkyo Foreign exchange market
} 
表 1 予想材料

\begin{tabular}{cl|l}
\hline$k$ & 予想材料 $x^{k}(t)$ & もとになる生データ \\
\hline 1 & 景気 & [米][日] GDP etc. \\
2 & 物価 & [米][日] 消費者物価指数 etc. \\
3 & 金利 & [米][日] 公定歩合, 長期金利 \\
4 & マネーサプライ & [米][日] マネーサプライ \\
5 & 貿易収支 & [米][日] 貿易収支 \\
6 & 雇用 & [米] 失業率 etc. \\
7 & 個人消費 & [米] 小売売上, 個人所得 \\
8 & 介入 & [米][日] 介入 \\
9 & 要人発言 & [米][日] 中銀総裁の発言 etc. \\
10 & マルク & ドル/マルク, 円/マルク \\
11 & 石油 & 石油価格 \\
12 & 政治 & 政情, 国際的な事件 \\
13 & 株 & [米][日] 株価 \\
14 & 債券 & [米][日] 債券価格 \\
15 & 短期トレンド 1 & 先週の変動値 $(\Delta R(t-1))$ \\
16 & 短期トレンド 2 & 変動の変動値 \\
& & $(\Delta R(t-1)-\Delta R(t-2))$ \\
17 & 長期トレンド & 5 週間の変動 \\
& & $(R(t-1)-R(t-6))$ \\
\hline
\end{tabular}

$R(t)$ : 期間 $t$ の為替レート (対数)

$\Delta R(t)=R(t)-R(t-1)$

\section{$2 \cdot 1$ AGEDASI TOF}

AGEDASI TOF は, 100 人のエージェントからなる マルチェージェントシステムを用いた円・ドルを扱う人 工外国為替市場モデルである . 各ェージェントは円・ド ル資産を持ち，乥の割合をレートに合わせて変化させる ことで利益を得ようとするディーラーを模している．

\section{$\S 1$ 入力データ}

入力されるデータは新聞記事 [日本 02] および相場解 説記事 [国際 02] に基づいて和泉らが景気，物価，金利， 介入などの 17 項目のレート変動要因の変化を 7 段階 $( \pm 3, \pm 2, \pm 1,0)$ にコーディングしたものである (表 1$)$. 正の值は伝統的な経済理論に従うとドル高要因となる予 想材料であり，負の值はドル安要因となる予想材料を意 味している.また，17 項目の内，1１4 の項目はファン ダメンタルズ要因 ${ }^{* 2}$ であり過去の相場解説記事などを元 にした外部から入力される予想材料である．一方，15〜 17 の項目はトレンド要因*3であり，長期と短期のトレン ドを過去のレートから計算しコーディングした予想材料 である。

一期間は現実世界の一週間に対応する.レート決定が 一回行われる一期間では次の 5 つのステップが実行され る(図 1).

\section{$\S 2$ 各ステップの内容}

\section{i. 知覚ステップ}

知覚ステップでは各エージェントが為替レートの変動要 因である予想材料 (表 $1 の) ~ x^{k}(t)$ を知覚する.AGEDASI TOF では全市場参加者の知覚は同じであると仮定され ているため, 全エージェントが同じデータを受け取る .

\footnotetext{
$* 2$ 為替レートに影響を与える経済の基礎的条件 .これらは為替 市場の外から入ってくる情報である.

*3 為替レートの動きの方向性のことでチャート分析によって得 られる．これらは為替市場内部の情報である．
}

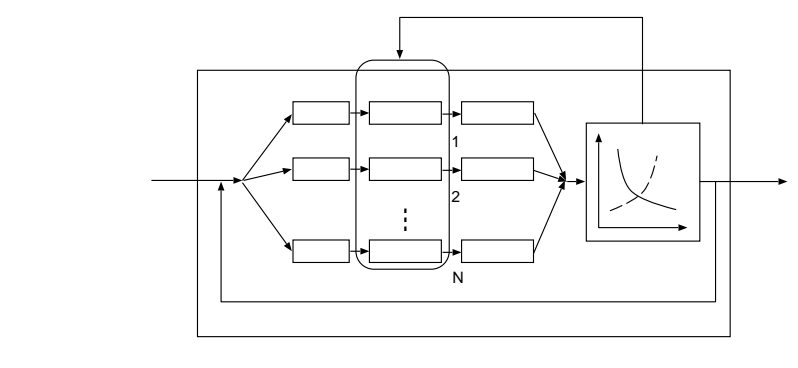

図 1 AGEDASI TOF のフレームワーク

ii. 予想形成ステップ

各エージェントのレートに対する予想形成は，レート (対数 $\left.{ }^{* 4}\right) R(t)$ の変動 $\Delta R(t)$ に対する予測值 $\mathbf{E}_{i}[\Delta R(t)]$ を求めることで行われる.各エージェントは光れ独 自の市場観を持っており，弚れは 17 種類の予想材料に対 する重みづけで表される . 各エージェントの予測レート 変動值は, 各予想材料と光の予想材料に対する重みづけ の積の和として定義される .

$$
\begin{aligned}
\mathbf{E}_{i}[\Delta R(t)] \equiv \alpha\left(\sum_{k=1}^{17} x^{k}(t) w_{i}^{k}(t)\right) \\
(1) \\
\left(\begin{array}{rl}
R(t): & \text { 期間 } t \text { の為替レート (対数 }) \\
\mathbf{E}_{i}[\Delta R(t)]: & \text { エージェント } i \text { の } \Delta R(t) \text { 予測値 } \\
x^{k}(t): & \text { 期間 } t \text { の予想材料 } k \text { の值 } \\
w_{i}^{k}(t): & \text { エージェント } i \text { の予想材料 } k \text { に } \\
& \text { 対する重みづけ } \\
& \text { ( } \pm 3, \pm 1, \pm 0.5, \pm 0.1,0 \text { の } 9 \text { 段階 }) \\
\alpha: & \text { スケール係数 }
\end{array}\right)
\end{aligned}
$$

iii. 戦略決定ステップ

戦略決定ステップでは各ェージェントが各自の予想に 基づき期待収益を最大にする最適ドル資産保有高を計算 し , ドルの売買要求量を決定する .

各エージェントの売買戦略は, 期間 $t$ における最適ド ル資産保有高が期間 $t-1$ のドル資産保有高よりも大き く(小さく)，かつレートが自分の予想したレートより も安く (高く) 有利な場合には, 弚の差の分だけドルを 買って (売って) 保有高を最適量に近づけようとすると いうものである .

iv. レート決定ステップ

各エージェントの売買戦略を市場全体で集積して，需 要と供給が均衡するような值にモデルの今期のレートを 決定する .

v. 学習ステップ

各エージェントの各予想材料に対する重みづけ $w_{i}^{k}(t)$ を 遺伝子 , 重みづけの列 $\mathbf{w}_{i}(t)=\left(w_{i}^{1}(t), \cdots, w_{i}^{17}(t)\right)$ を染

*4 レートの変動を元のレートに対する割合で考えるためにレー 卜を対数でとる．これは，100 円/ドルから 1 円変動すること と 200 円/ドルから 2 円変動することは等価であるという考え に基づく. 
色体とみなし，学習ステップでは Simple GA [Goldberg 89]に基づいた遺伝的アルゴリズムを用いて各ェージェ ントは情報交換，学習を行い，予想材料に対する重みづ けの列を変化させる . 学習ステップで行われる操作は淘 汰, 交叉, 突然変異の 3 つである .

まず,エージェント $i$ の期間 $t$ における適応度 ${ }^{* 5} F\left(\mathbf{w}_{i}(t)\right)$ を以下のようにレートの予測と実際のレートのずれをも とに定義する。

$$
F\left(\mathbf{w}_{i}(t)\right)=-\left|\mathbf{E}_{i}[\Delta R(t)]-\Delta R(t)\right|
$$

淘汰とは , 確率 $G$ (Generation Gap ) で選ばれたエージェ ント $i$ (全エージェント数 $N \times G$ 人) が, 適応度 $F\left(\mathbf{w}_{j}(t)\right)$ に比例する確率で選ばれた相手 $j$ から重みづけの列をコ ピーする操作である．つまり，各ェージェントは自分の 予想が正確であれば変更せず，予想が不正確であれば他 のエージェントが持つ適応度の高い重みづけの列に入れ 替えるのである．これは予測に失敗したディーラーが成 功したディーラーと情報交換を行うことによって自らの 予想方式を変更することにあたる．

交叉とは，ランダムに全ェージェントをペアにし，光 れぞれのペアの重みづけの列に対し，確率 $P_{\text {cross }}$ で一点 交叉を行う操作である .これはディーラー間のコミュニ ケーションによりお互いの意見を交換しあい，光の結果 予測方針を変更することにあたる。

最後に突然变異とは, エージェント $i$ があ重みづけ $w_{i}^{k}$ を, 確率 $P_{\text {mutation }}$ でランダムに変化させる操作であ る.これはディーラーがある予想材料に対して，思いつ きで新たな価值を設定することにあたる .

§ 3 AGEDASI TOF によるシミュレーション

AGEDASI TOF によるシミュレーションは, 実験対 象であるテスト期間とェージェントのトレーニングを行 うトレーニング期間から成る（図 2 ）。まず，テスト期間 の前の数年間をトレーニング期間とし, 現実のレートと レート予想材料のデータを用いてェージェントのトレー ニングを行う．トレーニング期間ではレート決定ステップ においてレート決定を行わず，現実のレートを系のレー トとして用いる．トレーニング期間は 20 回*6繰り返し， 現実のレートを用いた学習によってランダムに生成され たエージェントの重みづけはテスト期間直前の市場参加 者の状態に最適化される．以下，このトレーニング期間 の後 , 個々のエージェントが持つ重みづけ列 $\mathbf{w}_{i}(t)$ を初 期状態と呼ぶ．トレーニング終了後，現実のレート予想 材料のデータを用いてテスト期間のシミュレーションを 行う.このシミュレーションによって現れたレートの推 移をシミュレーションパス (simulation path) と呼ぶ .テ スト期間では現実のレートデータは用いず，各エージェ ントの売買行動によって決定する .

$* 5$ 厳密には, エージェント $i$ の期間 $t$ にとった予想方式 (予想 材料に対する重みづけの列 $\left.\mathbf{w}_{i}(t)\right)$ の適応度

*6 現実のレートをシミュレートする実験において ,十分な精度 が得られることから 20 回とした .

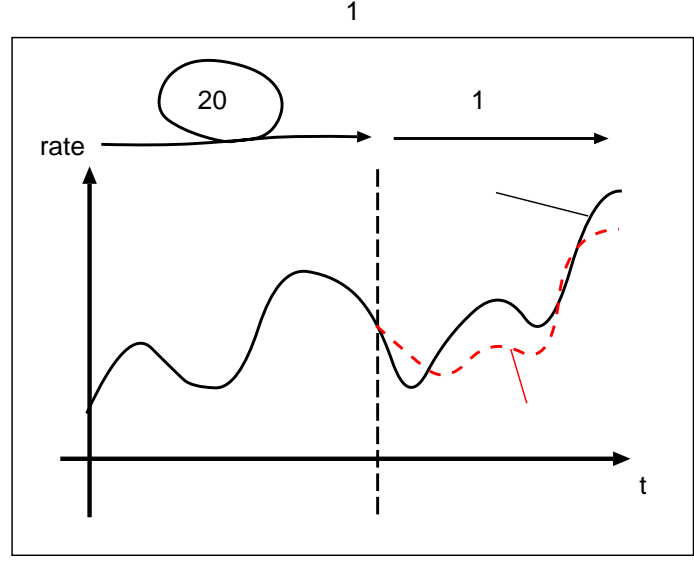

図 2 AGEDASI TOF によるシミュレーション

\begin{tabular}{|lc|cccccc|c|}
\hline & $k$ & 1 & 2 & 3 & $\cdots$ & 16 & 17 & \\
\hline 予想材料 & $x^{k}(t)$ & 1 & -3 & 0 & $\cdots$ & 2 & 0 & \\
\hline \hline agent $i$ & $w_{i}^{k}(t)$ & 3 & -0.1 & $\mathbf{0 . 5}$ & $\cdots$ & 0 & $-\mathbf{3}$ & 適応度: 高 \\
agent $j$ & $w_{j}^{k}(t)$ & 0 & 1 & $\mathbf{3}$ & $\cdots$ & 1 & $\mathbf{0 . 5}$ & 適心度: 低 \\
\hline
\end{tabular}

$\Downarrow$

\begin{tabular}{|ll|cccccc|c|}
\hline agent $i$ & $w_{i}^{k}(t+1)$ & 3 & -0.1 & $\mathbf{0 . 5}$ & $\cdots$ & 0 & $-\mathbf{3}$ & \\
agent $j$ & $w_{j}^{k}(t+1)$ & 3 & -0.1 & $\mathbf{3}$ & $\cdots$ & 0 & $\mathbf{0 . 5}$ & \\
\hline
\end{tabular}

図 3 提案手法による学習の例

\section{$2 \cdot 2$ 情報交換の仕組みの改良}

人工市場モデルを用いてシミュレーションを行うことの メリットとしてミクロレベルすなわちエージェントの状態， 行動を分析できることがあげられる．しかし，AGEDASI TOF ではェージェントの学習に Simple GA を用いてい るために光の行動が不自然になってしまっている．まず， 交叉において行われる重みづけの列の一点交叉は，対等 にレート予想材料の重みづけを入れ替えるという点て現 実のディーラーの情報交換としては説明できない不自然 な行動である．また，淘汰においてはレートの予想の正 確さを高めるために行うにもかかわらず，予想がより正 確だったエージェントの重みづけ列をすべてコピーして いる．乥こで本研究では，AGEDASI TOF における交 叉を廃止し，レートの予想に関係した重みづけだけをコ ピー対象とする淘汰による情報交換の仕組みを導入する．

图 3 に適応度の低いエージェント $j$ が適応度の高いエー ジェント $i$ から重みづけをコピーする例を示す .この例 で, 3 つめの予想材料と最後の予想材料は 0 でありレート 予想に無関係であるため, エージェント $j$ は光れらに対す る重みづけに関してはコピーを行わず, 自分の認識を変 えていない .この操作では, 適応度に無関係な重みづけを むやみにコピーしないことで各ェージェントが個性を失 うことを防いでいるとも言える．また，現実のレート予想 材料のデータを用いたシミュレーションでは本研究の情報 交換の仕組みを用いたモデルの方が AGEDASI TOF よ りも精度が高いという結果も得られている [Matsui 03b] . 


\section{3. 介入ェージェントの導入}

本研究では前章で述べた市場モデルに政府，中央銀行 に相当する介入ェージェントを導入する.介入が為替レー 卜に及ぼす効果については 2 種類あると言われている [渡 辺 94].1つは介入か外国通貨の需給に影響を与え，光れ を反映してレートか変化するというものである .これは ポートフォリオ・バランス効果と呼ばれている .もう 1 つは中央銀行の介入から市場参加者が将来の金融政策に 関する意图を読み取り，弚れに基づいて為替レートに関 する予想を変化させることでレートが変化するというも のである .これはシグナル効果と呼ばれている . 近年の 介入においてはシグナル効果の重要性か指摘されており， ポートフォリオ・バランス効果はシグナル効果と比べると かなり小さいという事例も報告されている [Dominguez 93, Ramaswamy 00] .しかし , AGEDASI TOF におい て介入は予想材料の 1 つにすぎず市場の需給に影響しな いため，これらの介入の効果の検証を行えなかった . ま た，AGEDASI TOF では実験を行う前にいつ，どれく らい介入するかをあらかじめ決定しておく必要があるた め, 市場の状態に応じた介入ができなかった . 本研究で は介入を行う機関をエージェントとして系に組み込むこ とで, これらの問題点を解消する.

介入ェージェントは以下の点で一般の市場参加者であ るディーラーェージェントと異なる．

目的：為替レートを目標範囲内に安定させることを目

的とする.ディーラーエージェントと異なり，取引

により利得が得られるかどうかとは無関係である . 各ステップ $(2 \cdot 1 \cdot 2$ 節 $)$ での行動:

・戦略決定ステップでは，介入量を決定する．

○一般に, 介入量は 1 ディーラーエージェント

の注文量よりも大きい .

○介入を行うことを市場に知らせる (シグナリ ング) 場合は, 介入ェージェントの行動が予 想材料の介入 $x^{8}(t)$ として知覚される.

・学習ステップにおいて, ディーラーエージェン 卜は $2 \cdot 2$ 節で述べたアルゴリズムで学習を行う が, 介入ェージェントは光れとは独立に強化学 習を用いて有効な介入政策を学習する。

[松井 02] では, 既存の介入政策をアルゴリズムとして実 装することで光の有効性を検証するシステムを作成して いるが, 本研究では自動的に介入政策を獲得するシステ ムを作成し，樣々な条件下での介入の有効性の検証を可 能にする .

\section{$3 \cdot 1$ 強化学習による介入政策の獲得}

介入ェージェントは, 強化学習によりレートの安定に 有効な介入政策を獲得することを目的とする . 介入エー ジェントが行う学習はディーラーエージェントにより構 成される市場の状態を知覚し，弚の状態に応じた行動を
学習するものであり，ディーラーエージェントのものと 比べてより市場全体を対象にした学習である．本研究で 用いる強化学習手法は Profit Sharing [Grefenstette 88] に基づいたものである . Profit Sharing は強化学習の 1 種で報酬の得られたエピソード*7 上のルールに対する重 みづけを強化していく方法である．1 つのルールは状態 $\mathrm{S}$ と光の状態で選択される行動 $a$ の組で表される .

状態 $\mathbf{S}$, 行動 $a$ の定義，およびルール $(\mathbf{S}, a)$ に対する 重みづけ $W(\mathbf{S}, a)$ を変化させる方法を以下に示す．

$\S 1$ 状 態

状態 $\mathrm{S}$ を, 現実の中央銀行が介入の際に考慮する市場 状態として以下のように定義する . 現在のレートや龹の 予測を考慮するのは当然であるが介入の効果は市場参加 者の介入に対する認識に左右されうる[渡辺 94] ため，介 入に対する重みづけの平均と標準偏差を加えて状態表現 とした .

$$
\begin{aligned}
& \mathbf{S} \equiv\left(\bar{E}, \sigma_{E}, \bar{w}^{8}, \sigma_{w^{8}}, x^{15}, R\right) \\
& \bar{E}=\sum_{k=1, k \neq 8}^{17} \bar{w}^{k} x^{k}
\end{aligned}
$$

ここで $x^{k}$ は $k$ 番目の予想材料, $\bar{w}^{k}$ は予想材料 $x^{k}$ に対 する全ディーラーェージェントの重みづけの平均值であ る.よって $\mathbf{S}$ の第 1 項 $\bar{E}$ はほぼレートの变動に対する予 測の平均となる ${ }^{* 8}$. 第 2 項 $\sigma_{E}$ は $E$ の標準偏差である. つまりどれだけディーラーの予測が集中しているかを表 している $\cdot \bar{w}^{8}, \sigma_{w^{8}}$ は全ディーラーエージェントの介入 に対する重みづけの平均と標準偏差である . また,$x^{15}$ は 短期トレンド $\Delta R(t-1)$ (表 1 参照)， $R$ は現在の為替 レートである.計算機実験を行う上て現実的な計算量に 収まるようにこれらの值は光れ光れ 5〜11段階の離散的 な値とした . 各離散值は, 実験過程で各值の変化を観察 し光の範囲と頻度をもとに設定したものである．

この状態表現を用いることでレートが目標値より高く (低く) かつ上がり (下がり) トレンドならドル売り（買 い) 介入を行う政策 (対称的 leaning-against-the-wind 政策 [渡辺 94]）を学習することも可能になる。

$\S 2$ 行 動

行動 $a$ は「どのように介入するか」を表す．すなわち， 介入の向き (ドル買いかドル売りか) と光の量である .

$$
a \equiv \frac{3 q}{Q}
$$

$a$ は 7 段階の離散的な值 $( \pm 3, \pm 2, \pm 1,0){ }^{* 9}$ をとる.$q$ が 実際の介入量であり，介入ェージェントの注文量となる . このとき, 注文レートは常に目標範囲の中央値としたに こ の值を以下, 目標レートと呼ぶ）。 $Q$ は最大介入量で, $a$

*7 エピソードとは選択されたルールの列である

*8 介入エージェントが操作できる介入の項目 $x^{8}$ が除かれてい るので全ディーラーの注文レートの平均とは完全には一致しな い.

$* 9$ 表 1 の他の予想材料に合わせてこの値とした 
が \pm 3 をとったときに介入量 $q$ が $\pm Q$ となる . この設 定で介入ェージェントは「レートが目標レートより低く， $a>0$ ならばドルを買う」,「レートが目標レートより高 く, $a<0$ ならばドル売る」というような介入を行うこ とができる．

また介入を行うことを市場に知らせる (シグナリング) 場合は , 行動 $a$ の值が兴のまま $x^{8}$ としてディーラーエー ジェントに知覚される . シグナリングを行わない場合は， $x^{8}$ は常に 0 となる.行動 $a$ は各ルールの重みづけ $W(\mathbf{S}, a)$ によるルーレット選択とした .

\section{$\S 3$ 報 酬}

各ルールは以下の 3 つの方法で評価され，ルールに対 する重みづけ $W(\mathbf{S}, a)$ を変化させる .

試行全体の評価

テスト期間全体でレートが目標範囲に入っていたら，エ ピソード上すべてのルール*10の重みづけを一樣に増加さ せる .

$$
W(\mathbf{S}, a) \leftarrow W(\mathbf{S}, a)+r
$$

\section{各週の評価}

式 (5) によるルールの重みづけの更新は， 1 試行で 1 回 しか行われず報酬を得るための条件も厳しいため, 式 (5) のみによる重みづけの更新では学習が進みにくいと予想 される．乥こで本研究では，学習速度の低下を防ぐため に各週で実行されたルールを以下の方法で評価し，光の ルールの重みづけを随時更新する .

(1) 各週において決定されたレートが目標範囲内かど うかで光の週のルールの重みづけを変化させる .

レートが目標範囲内の場合

$$
W(\mathbf{S}, a) \leftarrow W(\mathbf{S}, a)+\frac{r}{2}
$$

レートが目標範囲外の場合

$$
W(\mathbf{S}, a) \leftarrow W(\mathbf{S}, a)-\frac{r}{2}
$$

（2）介入したにもかかわらず取引できなかった場合， すなわちドル買い介入を行おうとしたが，決定した レートは目標レートよりも高かった，あるいはドル 売り介入を行おうとしたが，決定したレートは目標 レートよりも安かった場合には, 介入行動が市場の 需給に全く影響していないだけでなく、「レートを上 げるためにドル買い介入を行う」というような介入 の基本概念と照らし合わせても無䭾な行動であると 考えられる．したがって，このような場合は光の週 のルールの重みづけを減少させる .

$$
W(\mathbf{S}, a) \leftarrow W(\mathbf{S}, a)-\frac{r}{2}
$$

本研究では各ルールの初期重みを 1.0 , 報酬 $r$ を 0.1 と する*11 . 試行全体の評価, 各週の評価での重みづけ変化 値の比，および初期重みと報酬 $r$ の比は実験により学習 効率のよい値に設定した .

\footnotetext{
*10 ここでのエピソード長はテスト期間の長さと一致し , 評価さ れるルールの数はテスト期間の週の数と同じになる .
}

$* 11$ 現実の為替市場を前提にすると介入を行わない行動 $a=0$ を

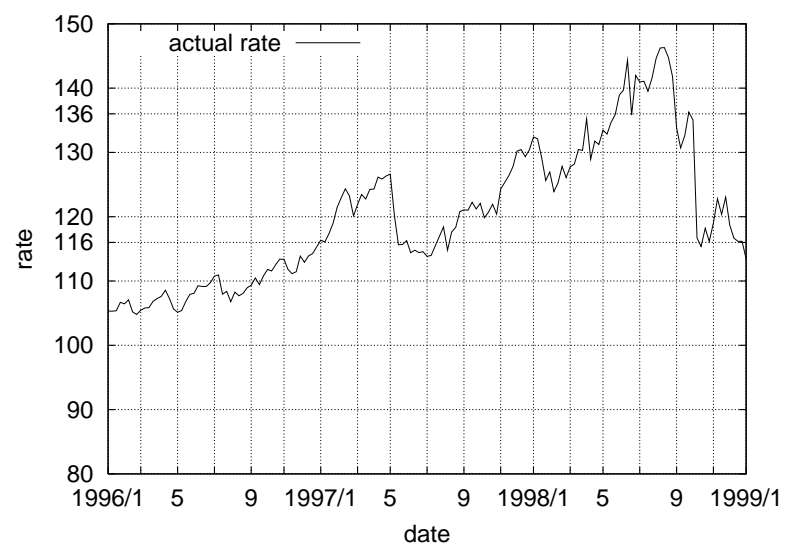

図 4 実験対象期間の現実のレート

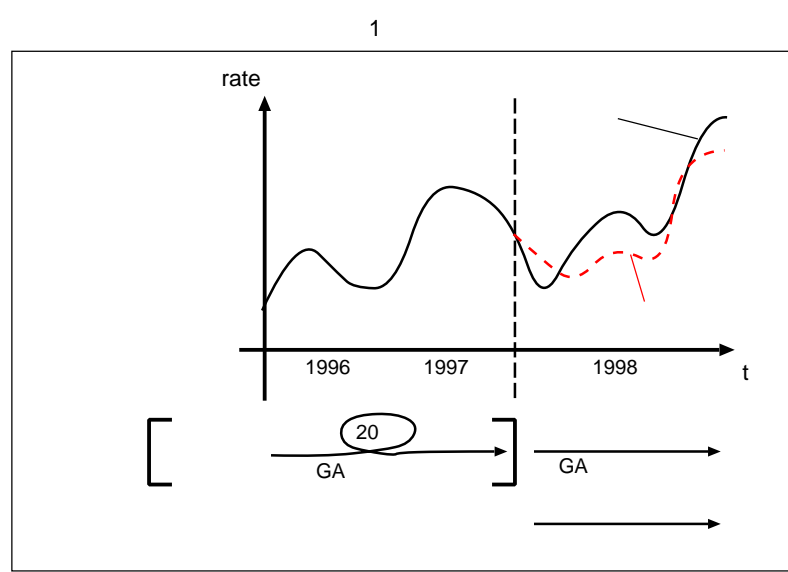

図 5 介入ェージェントを用いたシミュレーション 実際の実験では [] 内の過程を保存した初期状態を用 いることで省略している

4. 介入エージェントを用いたシミュレーション

本章では前章て提案した介入ェージェントを用いて，有 効な介入政策を獲得する実験の報告を行う．また，兴の 有効性の検証のために ,

ランダム介入ェージェントランダムに介入を行う 全知覚介入エージェント 全市場参加者の行動を観察し，

常に最適な介入を行う

全知覚ルールテーブル 全知覚介入ェージェントの行動

に基づき，強化学習介入ェージェントの状態表現の

枠組みで作成した介入規則による介入を行う を順次定義し，本章および 5 章で実験結果を比較する．

\section{$4 \cdot 1$ 実 験 の 設 定}

1998 年 10 月，ドルー円レートは 1 週間で 20 円も下落 した (図 4) .この 1998 年をテスト期間として実験を 行う. まず, 1996 年 1 月から 1997 年 12 月の 2 年間を

デフォルトとする設定も考えられるが, 本研究では介入の効果 を現出させることを目的とするため，すべての状態で $a=0$ を 含めた 7 種類の行動からランダムに選、引晸策を初期政策とし ている。 
表 2 介入量とシグナリング

\begin{tabular}{c|cc}
\hline & 最大介入量 $Q$ & シグナリング \\
\hline$\left(30 \overline{q_{a}}\right.$, yes $)$ & $30 \overline{q_{a}}$ & 行j \\
$\left(10 \overline{q_{a}}\right.$, yes $)$ & $10 \overline{q_{a}}$ & 行j \\
$\left(\overline{q_{a}}\right.$, yes $)$ & $\overline{q_{a}}$ & 行j \\
$\left(30 \overline{q_{a}}, \mathrm{no}\right)$ & $30 \overline{q_{a}}$ & 行わない \\
$\left(10 \overline{q_{a}}, \mathrm{no}\right)$ & $10 \overline{q_{a}}$ & 行わない \\
$\left(\overline{q_{a}}, \mathrm{no}\right)$ & $\overline{q_{a}}$ & 行わない \\
$\overline{q_{a}}: \quad$ 介入エージェントが存在しないシミュレーション \\
\multicolumn{2}{c}{ でのディーラーェージェントの平均注文量 }
\end{tabular}

トレーニング期間として AGEDASI TOF と同樣に炎の 期間の現実のレートとレート予想材料のデータを用いて ディーラーェージェントのトレーニングを行う．予想材 料の重みづけがランダムな゙状態のディーラーエージェン トに対しトレーニング期間を 20 回繰り返すトレーニン グを 100 組行い，乥れぞれを 1998 年直前のディーラー エージェントの初期状態として保存した . 兴の後 , テス 卜期間である 1998 年のシミュレーションを 200,000 試行 繰り返した . 各試行のテスト期間開始時にはあらかじめ 作成した 100 組のディーラーエージェントの初期状態の データを順に用いた .つまり，100 種類の初期状態につい て光れ光れ 2000 回シミュレーションを行うことになる. 介入エージェントの各ルールに対する重みづけ $W(\mathbf{S}, a)$ の表 (ルールテーブル) は, 1 回のシミュレーションご とに初期化は行わず，保持したまま次のシミュレーショ ンを行う.この実験の 1 試行の内容を図 5 に示した . レートの目標範囲 単純化のために介入エージェントの レートの目標範囲は $t$ によらず，常に 116〜 136 円 とした.

最大介入量 $Q$ とシグナリング 介入量の大小およびシ グナリングの有無による介入の効果を比較するため に表 2 の設定*12 の実験を行った .

ディーラーェージェントの学習 本研究のモデルではテ

スト期間において , ディーラーェージェントと介入 エージェントが相互に学習を行う．このとき，お互 いの学習が影響しあうことで有効な戦略を学習する ことが難しくなる.これは同時学習問題と呼ばれ， マルチェージェント学習の難しさの 1 つとして知ら れている [荒井 01] . 本研究でも , [松井 03a] におい て同時学習が介入の成功率を下げる原因となること をすでに示している．光こでテスト期間内でディー ラーエージェントが学習を行わない場合 (同時学習 なし) と行う場合 (同時学習あり) の実験を光れ光 れ行った .

評価方法 テスト期間のレートが常に介入エージェント の目標範囲に入っているシミュレーションパス (図

$* 121998$ 年 4 月の東京外国為替市場の一日平均の取引金額は 1,486 億ドル [吉本 00，p. 11] であり，対象期間に近い 1999 年 4 月 10 日に 202 億ドルの介入 [財務 04] が行われたことを 考えると, 本研究の介入量の設定は妥当な範囲であると考えら れる

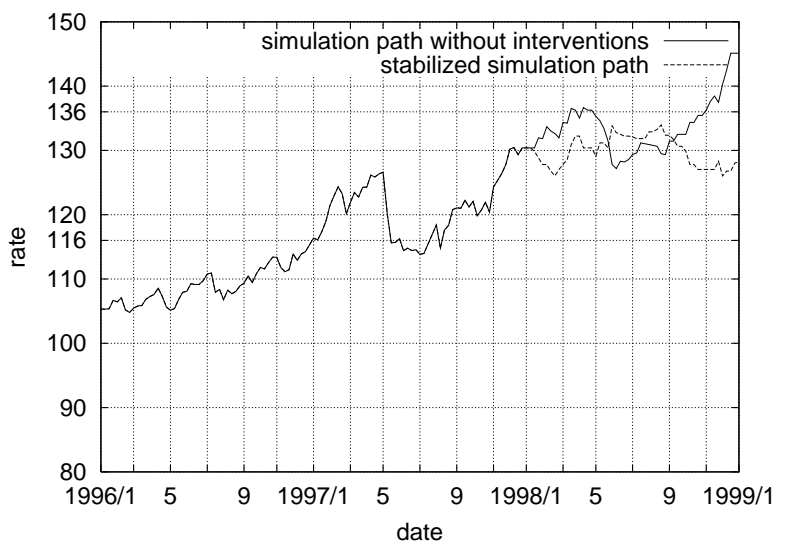

図 6 ディーラーエージェントが学習を行わず介入が行われない場 合のある初期状態に対するシミュレーションパスと安定パス

6) , すなわち介入が成功したシミュレーションパス を安定パスと呼ぶ . 本研究は, シミュレーション回 数に占める安定パスの割合 (レートの安定率) で評 価を行った .

\section{$4 \cdot 2$ 実 験 結 果}

まず，全体の結果から 1 つの初期状態に対する結果を 取り出したものを示す.ディーラーエージェントが学習 を行わない場合，介入ェージェントが介入を行わなけれ ば確率的な要素が全くないためシミュレーションパスは 常に同じになる (図 6)．この初期状態に対するディー ラーエージェントが学習を行わない場合の結果を図 7 に， 学習を行う場合の結果を図 8 に示す．また，全体の結果 を表 3 の「強化学習」欄に示す. 全体の結果では, $3 \cdot 1 \cdot 2$ 節で定義した 7 種類の介入エージェントの行動をランダ ムに選択するランダム介入*13 (表 3 の「ランダム」欄) と比較した .ここでランダム介入が, 注文レートが一定 ではないランダムな売買と異なることに注意が必要であ る.ランダム介入では強化学習を行う介入ェージェントと 同樣に注文レートが目標レートで固定されており，レー トが注文レートより高い (安い) 場合, ドル買い (売り) 取引は行わないため介入行動の選択がランダムであって もある程度の効果が期待できる。

以下に実験結果の検証を行う.

\section{介入量}

すべての設定で介入量が大きいほどレートの安定率が 増加している．これは単純に市場内での影響力が増すこ とか理由であると考えられる .

シグナリング

介入量が同じ場合 , ディーラーエージェントが学習を 行う場合 , 行わない場合ともにシグナリングを行った方

\footnotetext{
*13 介入エージェントの学習を行う前の段階では, 7 種類のすべ ての行動の重みづけが同じであるので, ランダム介入は未学習 状態の強化学習介入ェージェントによる介入ということもでき る
} 
表 3 全初期状態に対するレート安定率 (100 初期状態 $\times 100$ 回平均)

\begin{tabular}{r|c|c|c|c|c|c|c|c}
\hline & \multicolumn{3}{|c|}{ ディーラーエージェントが学習を行わない場合 } & \multicolumn{3}{|c}{ ディーラーエージェントが学習を行う場合 } \\
\hline $\begin{array}{c}\text { 介入エージェ } \\
\text { ントの種類 }\end{array}$ & ランダム & 強化学習 & $\begin{array}{c}\text { 全知覚ルー } \\
\text { ルテーブル }\end{array}$ & 全知覚 & ランダム & 強化学習 & $\begin{array}{c}\text { 全知覚ルー } \\
\text { ルテーブル }\end{array}$ & 全知覚 \\
\hline$\left(30 \overline{q_{a}}, \mathrm{yes}\right)$ & $53.8 \%$ & $69.1 \%$ & $75.2 \%$ & $100.0 \%$ & $48.3 \%$ & $57.1 \%$ & $73.3 \%$ & $99.1 \%$ \\
$\left(10 \overline{q_{a}}, \mathrm{yes}\right)$ & $43.7 \%$ & $57.5 \%$ & $63.0 \%$ & $99.0 \%$ & $33.3 \%$ & $38.8 \%$ & $53.4 \%$ & $94.0 \%$ \\
$\left(\overline{q_{a}}, \mathrm{yes}\right)$ & $35.7 \%$ & $47.7 \%$ & $50.1 \%$ & $97.0 \%$ & $19.1 \%$ & $23.6 \%$ & $31.3 \%$ & $85.3 \%$ \\
$\left(30 \overline{q_{a}}, \mathrm{no}\right)$ & $53.5 \%$ & $56.6 \%$ & $58.1 \%$ & $94.0 \%$ & $45.7 \%$ & $48.9 \%$ & $59.7 \%$ & $95.0 \%$ \\
$\left(10 \overline{q_{a}}, \mathrm{no}\right)$ & $40.0 \%$ & $42.3 \%$ & $43.7 \%$ & $80.0 \%$ & $27.9 \%$ & $28.8 \%$ & $35.9 \%$ & $83.0 \%$ \\
$\left(\overline{q_{a}}, \mathrm{no}\right)$ & $31.2 \%$ & $31.5 \%$ & $34.5 \%$ & $68.0 \%$ & $14.3 \%$ & $13.6 \%$ & $18.9 \%$ & $46.9 \%$ \\
\hline
\end{tabular}
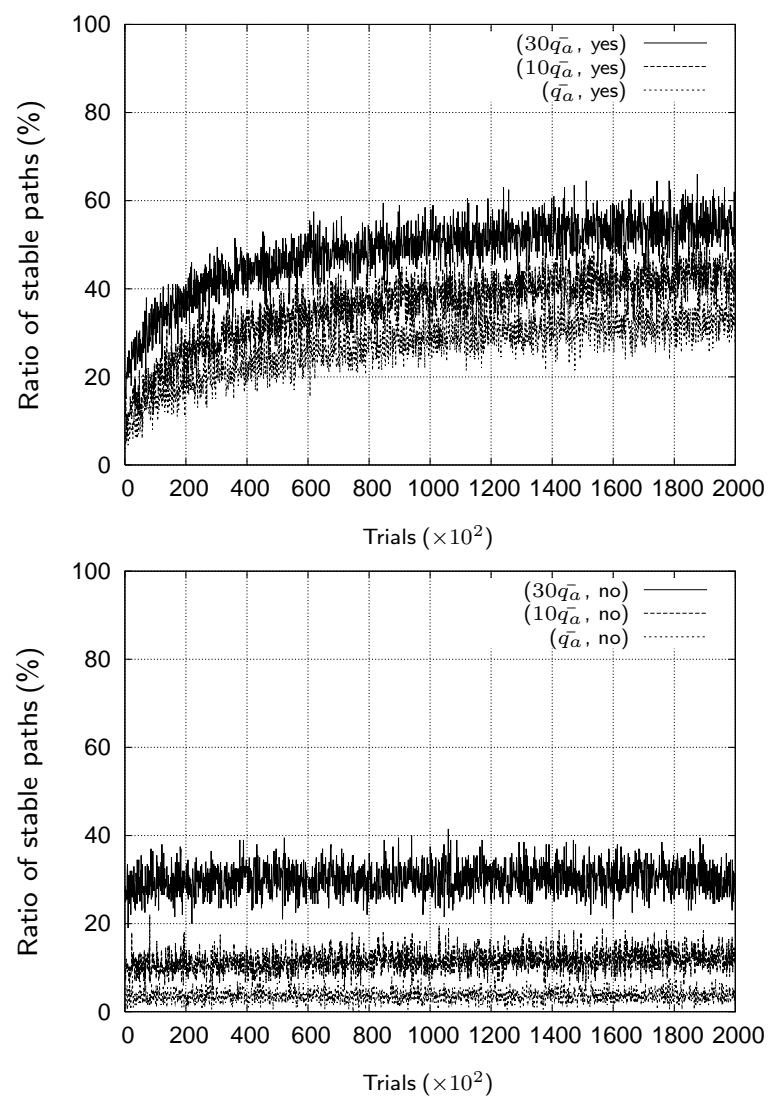

図 7 ある初期状態に対する同時学習が起こらない場合の試行回数 とレート安定率 (200 回平均)

がよりレートを安定させることに成功している .この結 果は介入においてシグナル効果の影響が大きいことを示 すものである .

同時学習問題

1 初期状態に対する結果で介入量が小さくディーラー エージェントが学習する場合は学習回数が少ないときに レートの安定率が一度，10\%ほども低くなっている.こ れは市場への影響力が小さいために，学習初期に有効な 戦略を模索する行動がディーラーの重みづけを擋乱して しまっていると考えられる .この現象はディーラーェー ジェントが学習する場合のみ起こることであり，同時学 習問題が顕著に現れている例である。

また , 1 初期状態に対する結果においてこの初期状態で は図 6 で示したようにディーラーエージェントが学習を
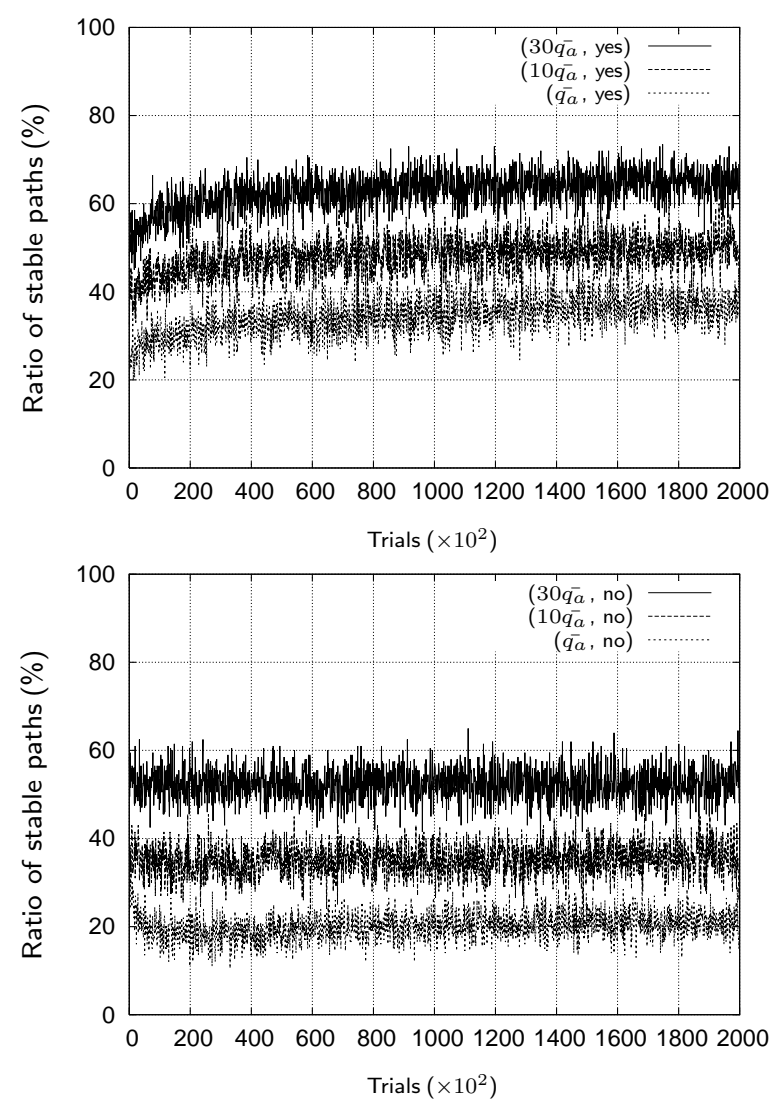

図 8 ある初期状態に対する同時学習が起こる場合の試行回数と レート安定率 (200 回平均)

行わない場合，介入を行わなければ決して安定パスとは ならない，一方, 同じ初期状態でもディーラーエージェン 卜が学習を行えは確率的な要素があるため, 介入を行わ なくても安定パスとなる可能性がある．弚のために，結 果を比較するとディーラーエージェントが学習を行う場 合の方が実験開始時，また最終的にもレート安定率が高 くなっている．しかし，全体の結果を見るとディーラー エージェントが学習を行う場合は, 学習を行わない場合 に比べてレートを安定させることができていない .これ は，同時学習問題に起因していると考えられる．

\section{各エージェントの学習}

介入の設定やディーラーエージェントが学習を行うか どうかにかかわらず, 介入ェージェントが学習で獲得し た介入政策では,レートが目標レートよりも低い(高い) 
場合, 以下の $(\mathrm{a})>(\mathrm{b})>(\mathrm{c})>(\mathrm{d})$ の状態の順によりド ル買い (売り) 介入を行う傾向か溞かった．

(a)・レートが目標レートよりも低く(高く),

・下がり (上がり) トレンドで，

・ディーラーェージェントの予測平均がドル安 (高) .

(b)・レートが目標レートよりも低く (高く),

・ディーラーェージェントの予測平均がドル安 (高) .

(c)・レートが目標レートよりも低く (高く),

・下がり (上がり) トレンド.

(d)・レートが目標レートよりも低い(高い) .

この結果から, 介入ェージェントは学習結果として対称 的 leaning-against-the-wind 政策を獲得したことか確認 された . また，すぐに変化する可能性のある短期トレン ドよりも次週のレートへの影響の大きいディーラーエー ジェントの予測を重視する介入行動を学習したことがわ かる .

次にシグナリングを行う介入ェージェントの行動によ る , ディーラーェージェントの介入に対する重みづけの 変化について述べる . 本研究の対象期間では, 全初期状 態中のほとんどのエージェントが介入に対して正の重み づけをしていた .この実験序盤では，介入量が小さい介 入ェージェントによるほぼランダムな介入に対しては， 徐々に負の重みづけを持つディーラーエージェントか増 えるという変化が見られた .これは介入の影響力が小さ いためにレートがシグナルとは逆の変化をすることが頻 繁に起こり，弚の際にシグナルに従うレートの予測をし たディーラーエージェントが重みづけを変更するためだ と考えられる.一方，実験終盤では介入量の設定を問わ ず重みづけはほとんど変化しなかった .これは介入の効 果がシグナル通りに現れているためにディーラーエージェ ント間で介入に対する重みづけか変更されない状況であ る.このような市場では介入のシグナル効果が大きく，介 入ェージェントの行動次第で市場全体をある程度操作す ることが可能だと考えられる .

\section{5. 介入量と強化学習モデルの検証}

本章では，前章で報告した実験における介入量の査定 と強化学習モデルの妥当性を検証する .このため, 市場 の各ディーラーエージェントの行動をすべて第三者的に 観察できる介入ェージェントを仮想し，各週において最 適な介入行動*14をとることができるとしたら，どのくら いレートを安定させることが可能か実験を行った . 弚の 後 , この理想的な介入を上限と考えたときとの比較にお いて , 本実験の設定の実効性と問題を議論する.本章では この理想的な介入を行うェージェントを全知覚介入エー

*14 ここでの最適な介入行動とは, 各週のレートを目標レートに 最も近づけることができる介入行動である.あくまでも各週の レートのみを考慮する行動であり, 長期的なレートの変化は考 慮していない。
ジェントと名づけ, 強化学習介入エージェントと同樣に $3 \cdot 1 \cdot 2$ 節で定義した 7 種類の行動を行うものとする.

\section{$5 \cdot 1$ 介入量の検証}

前章の強化学習介入ェージェントの代わりに全知覚介 入ェージェントを用いた実験を行い，各最大介入量の妥 当性を検証した . 結果を表 3 の「全知覚」欄に示す．

どの設定でも強化学習によって獲得された介入政策よ り圧倒的に安定率が高かった .このことは現在の介入量 の設定でレートをより安定させる介入政策を実行可能で あることを示している .

\section{$5 \cdot 2$ 全知覚ルールテーブルによる介入}

次に, 全知覚介入ェージェントを用いて本研究の強化 学習モデル (状態表現, ルールの重みづけの更新方法) の検証を行う .

まず検証の準備として , 各介入設定 (介入量 , シグナリ ングの有無) について关れ攵れ 30000 試行（100 初期状 態 $\times 300$ 回) の実験を行った . 谷の際に全知覚介入エー ジェントがとる行動に基づき，強化学習介入ェージェン 卜の状態表現の枠組みでルールテーブルを作成する.(全 知覚ルールテーブルと呼ぶ）この全知覚ルールテーブル は, 強化学習モデルの状態表現を用いた際の最適介入政 策であると考えることができる . 全知覚ルールテーブル に基づいて介入することでその際のレートの安定率が高 く, $5 \cdot 1$ 節の全知覚介入ェージェントの安定率に近けれ ば本モデルの状態表現，すなわち介入ェージェントの知 覚は十分であり，よりレートを安定させるためには重み づけの更新方法などを改良すべきであることがわかる． 逆に安定率が低ければ状態表現が不十分であることを示 している．また，強化学習介入エージェントによる安定 率が , 全知覚ルールテーブルによる安定率に近ければ状 態表現を除く本強化学習モデルは十分機能していると言 える。

実験結果を表 3 の「全知覚ルールテーブル」欄に示す． レート安定率は, すべての設定で全知覚介入ェージェン トによるものよりも $25 〜 50 \%$ も低く，現在の状態表現で は明らかに不十分であり不完全知覚が問題になっている ことを示している.一方で, 強化学習介入エージェント の結果は全知覚ルールテーブルによるものには及んでい ない.ディーラーェージェントが学習を行わない場合に は光の差は最大でも $6 \%$ ほどで，ある程度学習できてい ると言えるがディーラーエージェントが学習を行い同時 学習が起こる場合では最大で $16 \%$ も差があり，この結 果は同時学習問題が起こっていることを実験的に示して いる。

\section{$5 \cdot 3$ 状態表現の粒度に関する考察}

本節では強化学習モデルにおける状態表現の粒度につ いて議論する . 全知覚介入ェージェントは, 遭遇した状 
態すべてに対して最適な行動をとることができた .これ はつまり本研究の状態表現と比較すると，より詳細な状 態表現によって常に一意に行動を決定することが可能だ ということである. 逆に本研究の状態表現は全知覚介入 エージェントのものと比べて非常に粗いために全知覚介 入ェージェントによってルールテーブルを作成しても , 一 状態に対する行動を一意に決定することができない，光 こで作成した全知覚ルールテーブルを分析し，各状態に おいて最も強化された行動が全知覚ルールテーブルに基 づいて行動を選択した場合，どれだけの確率でとられる かを調べた .この確率が $100 \%$ に近い状態が多ければ全 知覚介入ェージェントと同樣に行動をほぼ一意に決定す ることができ，現在の状態表現でも十分であるというこ とができる．

本研究の実験における行動選択の統計をとつた結果，ど の介入設定でも常に最も強化された行動が選択される状 態は全状態数の中の $1.5 \sim 10 \%$ であり，最も強化された 行動が $75 \%$ 以上の確率で選択される状態も全状態数の中 の 20〜35\%と低かった .これでは, 各状態において行動 の選択にばらつきが生じることになり常に最適な介入を 行うことが難しい．このことから，やはり介入ェージェ ントの現在の状態表現では知覚が不十分であることがわ かる.しかし, 本研究の状態表現は現実の市場に則した ものであるため，これは現実の中央銀行の知覚能力に限 界があることを適切に表現するものである．

\section{6. おわりに}

本研究では, 現実の政府・中央銀行に当たる介入ェー ジェントを人工外国為替市場モデルに導入することで介 入効果の分析, また強化学習により自動的に有効な介入 政策を獲得するシステムを作成し，このシステムを用い て為替介入におけるシグナル効果を検証した，光の結果， ディーラーェージェントが介入を知覚しない場合に比べ て知覚する場合の介入の効果は大きく，介入においてシ グナル効果の影響は大きなものであることを示した .

本研究て提案した強化学習介入エージェントによる介 入は, 介入量が十分であるにもかかわらず全知覚介入エー ジェントと比較して安定率が大きく下回っている．これ は $5 \cdot 2$ 節および $5 \cdot 3$ 節で検証したように本研究で定義 した強化学習の状態表現, すなわち現実の中央銀行の知 覚能力の限界を示している．また，ディーラーエージェ ントが学習を行う場合には同時学習問題が起こり，有効 な政策の学習が困難になるため強化学習介入ェージェン 卜による介入の安定率は全知覚介入テーブルによる介入 (5・2 節) よりも低くなっている. 特に介入量が少なくシ グナリングを行わない場合は, 顕著でランダム介入より も低くなっている

これらの問題はマルチェージェント学習の課題であり， 解決が困難であると考えられる. しかし, 本研究の強化
学習介入ェージェントはシグナリングを行う場合には行 わない場合に比べてレートを安定させることに成功して いる .これは, 大きな力を持つ介入エージェントがうま く他のエージェントの行動を誘導しているからだと思わ れる. 本研究の対象である外国為替市場における介入で は介入ェージェントがシグナリングを有効に行うことで マルチェージェント学習の問題を解消することを期待で きる. 本研究の今後の課題は , シグナリングによる市場 への影響の微視的な分析を行うことでどのようなシグナ リングが有効であるかを調へ， シグナリングをより有効 に活用する手段を発見することである .

\section{$\diamond$ 参 考 文 献 $\diamond$}

[荒井 01] 荒井 幸代: マルチェージェント強化学習一実用化に向 けての課題・理論・諸技術との融合一, 人工知能学会誌, Vol. 16, No. 4, pp. 476-481 (2001)

[Dominguez 93] Dominguez, K. M. and Frankel, J. A.: Does Foreign Exchange Intervention Work? Institute for International Economics, Washington, DC (1993)

[Goldberg 89] Goldberg, D. E.: Genetic algorithms in search, optimization, and machine learning, AddisonWesley Publishing Company (1989)

[Grefenstette 88] Grefenstette, J. J.: Credit Assignment in Rule Discovery Systems Based on Genetic Algorithms, $M a-$ chine Learning, Vol. 3, pp. 225-245 (1988)

[和泉 00] 和泉 潔, 植田 一博: 人工市場アプローチによる為替シ ナリオの分析, コンピュータソフトウェア, Vol. 17, No. 5, pp. 47-54 (2000)

[国際 02] 国際金融情報センター: 市場解説 (1995-2002)

[松井 02] 松井 宏樹, 東条 敏 : 介入エージェントを用いた人工市 場アプローチによる介入政策の分析, 第 16 回人工知能学会全国 大会 $(2002)$

[松井 03a] 松井 宏樹, 永田 裕一, 東条 敏 : 人工市場アプローチ における強化学習を用いた介入政策の分析, 第 131 回情報処理 学会知能と複雑系研究会 (2003)

[Matsui 03b] Matsui, H. and Tojo, S.: Artificial Market with Intervention Agent, in Proceedings of the 1st Indian International Conference on Artificial Intelligence (2003)

[日本 02] 日本経済新聞社：「金融アウトルック」，日曜版，日本 経済新聞 (1995-2002)

[Ramaswamy 00] Ramaswamy, R. and Samiei, H.: The YenDollar Rate : Have Interventions Mattered?, IMF Working Paper (2000)

[渡辺 94] 渡辺 努 : 市場の予想と経済政策の有効性, 東洋経済新 報社 (1994)

[吉本 00] 吉本 佳生 : ニュースと円相場から学、使える経済学入 門, 日本評論社 $(2000)$

[財務 04] 財務省 : 外国為替平衡操作の実施状況 (2001-2004), http://www.mof.go.jp/1c021.htm

\section{〔担当委員 : 和泉 潔〕}

2004 年 7 月 14 日 受理 


\section{一著 者 紹 介以

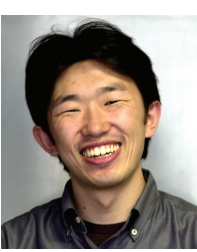 \\ 松井 宏樹 \\ 2000 年京都産業大学理学部物理学科卒業. 2002 年北陸 先端科学技術大学院大学情報科学研究科博士前期課程修了. 現在, 同大学同研究科博士後期課程在学中. マルチエージェ ントシステムと強化学習に興味を持つ。

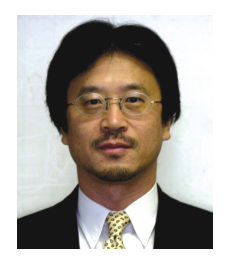 \\ 東条敏(正会員) \\ 1981 年東京大学工学部計数工学科卒業, 1983 年東京大学 大学院工学系研究科修了. 同年三菱総合研究所入社. 1986- 1988 年, 米国カーネギー・メロン大学機械翻訳センター 客員研究員. 1995 年北陸先端科学技術大学院大学情報科 学研究科助教授, 2000 年同教授. 1997-1998 年ドイツ. シュトゥットガルト大学客員研究員 . 博士 (工学). 自然言 語の形式意味論, オーダーソート論理, マルチェージェン 卜の研究に従事, 情報処理学会, 人工知能学会, ソフトウェ 乃科学会, 言語処理学会, 認知科学会, Folli 各会員.}

